\title{
Comparative Analysis of Insurance Premiums in Serbia and Bosnia and Herzegovina - Multiple Linear Regression Analysis Model
}

\author{
Tijana Kaličanin $^{1 *}$ | Sandra Kamenković ${ }^{1}$ | Ivana Simeunović ${ }^{1}$ \\ 1 University Union, Belgrade Banking Academy - Faculty of Banking, Insurance and Finance, Belgrade, Serbia
}

\begin{abstract}
In the last few years, the global insurance market has shown a trend of concentration growth, which was conditioned by the processes of mergers and acquisitions in insurance. The aim of this paper is to make a comparative analysis of insurance premiums in Serbia and Bosnia and Herzegovina. Dynamic analysis of market concentration indicators calculated on the basis of absolute amounts of premiums indicates that the insurance market in Bosnia and Herzegovina is characterized by low concentrated supply, i.e. there is greater equality of market share in relation to high inequality and high concentration among market participants in the insurance sector of the Republic of Serbia. Having applied the multi-linear regression model in order to analyze the impact of selected macroeconomic indicators on the amount of insurance premiums in the period 2000-2017, it can be concluded that the greatest impact on the amount of the premium in Bosnia and Herzegovina had Gross Domestic Income and Wage and Salaries Workers. In the Republic of Serbia, the greatest influence on the amount of premium in the observed period had the Average Net Salary, Households and Final Consumption Expenditure and Gross Domestic Income.
\end{abstract}

Key words: insurance premiums, insurance sector, multiple linear regression analysis model

JEL Classification: C30, G22, L19

\section{INTRODUCTION}

In the last two decades, countries of Central and East Europe have experienced tremendous changes in the political, cultural, social and economic environment. Central and East European financial system has been rapidly developing during the last couple of years, contemporary regulations have been introduced and new financial institutions have been established contributing to the maintenance of macroeconomic stability in the region. Nonetheless, the macroeconomic sector in the region, underdeveloped even before the recession took place, has been a highly risky place for investments and unstable in comparison with Western Europe (Kaličanin \& Hanić 2016a). The insurance market in the Western Balkans is characterized by significant changes caused by different economic growth pace. Countries preparing to become members of the European Union are carrying out faster reforms, and there is also a significant inflow of foreign capital due to a reduction of financial and political risks (Novović-Burić et al. 2017).

In this paper, the insurance sectors were analyzed in the Republic of Serbia and Bosnia and Herzegovina. In addition to the transition process in both countries, these countries have

\footnotetext{
*Corresponding author, e-mail: tijana.kalicanin@bba.edu.rs
} 
undergone similar political and economic changes in the past decade. Both insurance markets have passed through the process of integration and internationalisation. In addition to many similarities characteristic for these two markets, there are substantial differences that are reflected in the number of residents, the number of insurance companies, the market structure, the participation of the market leader, and the number of companies with foreign capital.

The market of a country is as developed as its competition is able to function on it. Competition has to be constantly stimulated and protected by mechanisms in line with the European integration processes and policy focused on market economy development. Competition as such has been a particularly sensitive issue in transitional countries such as

Serbia and countries in the region. Changing the number of insurance companies on the market influenced significantly the formation of a group of leaders in the insurance market as well as strengthening the position and increasing the individual market share of the leader (Kaličanin \& Lazić, 2018).

Initial structural changes raised an issue and brought about the need for a higher competitiveness in Serbia. Every country aspiring to join the EU and integration processes ought to develop legal norms and apply the EU regulations (Kaličanin \& Hanić 2016a). In recent years, the insurance sector has become a significant factor in the development of the overall financial and economic system. In the first part of the paper, insurance markets and level of competitiveness were analyzed. Competitiveness in the market has led to changes in the balance sheet structure of the entire financial sector as well as the position of individual insurance companies in previous years. The insurance sector is extremely important for the economy of a country, not only from the point of view of security and protection from different types of risks but also from the point of view of the overall economic development and improvements in the functioning of the financial market. In the second part of the paper, the focus is on the analysis of insurance premiums and the impact of selected macroeconomic indicators on premiums using the multi-linear regression model.

\section{LITERATURE REVIEW}

There are many analyses which deal with insurance premiums and economic growth. Outreville (1990), Zhi (1998), Beck and Webb (2003), Webb et al. (2002) have shown a very strong interaction between insurance premiums and GDP despite different periods and country patterns. Analyses mainly suggest that higher GDP growth rates have an impact on economic activity growth, which leads to assumptions about a positive correlation between GDP growth rate and demand for insurance.

Haiss and Sumegi presented very extensive research in 2008, which led to the conclusion that there is a correlation between insurance and GDP growth in EU-15 countries with developed financial markets as well as short-term linkages between GDP and non-life premiums on a sample of CEE countries. Serbia and Bosnia and Herzegovina are selected for this research because very few authors have analyzed this region from the insurance aspect.

Novovic-Buric et al. (2017) explored the influence of certain factors on the purchase of insurance products through a panel analysis. Western Balkan countries were analyzed in the period from 2005 to 2015, and the results show that most of the economic factors affect total life premiums. The demand for life insurance has a significant and positive impact on GDP and wages, while the influence of unemployment and interest rates is negative.

Dragos (2014) used the fixed and random effects model in the analysis, which entailed 17 countries in Asia and Central Eastern Europe. The aim was to compare emerging markets in Europe characterised by market economies and emerging markets in Asia, which are predominantly planned economies in terms of the impact of economic performance on life and non-life insurance. It has been noted that the differences certainly exist. The results concerning the CEE, taking into consideration the countries which are analyzed in this research have shown 
that income and education have a positive impact on the insurance demand, while urbanisation has shown a significant impact on non-life insurance. On the other hand, income distribution negatively influences the demand for insurance.

Kjosevski (2012) analysed the determinants of life insurance demand in Central and Southeastern Europe by using fixed-effect panel models in the period 1998-2010. The results show that in terms of life insurance, the most significant predictors are the following: high GDP per capita, inflation, health expenditure, level of education and the rule of law.

Mitra (2017) analysed the impact of economic, demographic and cultural factors on life insurance consumption in $28 \mathrm{EU}$ countries. The focus was on the emerging East European economies, given that in the analysed period 2009-2014, there were significant reforms of the insurance sector in these countries. The results show that the higher GDP is an indicator of higher wages and higher levels of economic activity, the more positive impact on insurance demand.

Ward and Zurbruegg (2002) analysed 37 countries in the period 1987 - 1998 with the intention to point to the links between insurance premiums and various legal and political factors, as well as economic and social factors. The analysis has shown that the consumption of life insurance products is under stronger influence of GDP in Asia than in OECD countries, which is an expected result given that in the OECD countries there is a considerably higher average income level and that 'S curves' suggest that at higher levels of income the demand for insurance is less susceptible to the revenue growth.

Bianchi et al. (2011) analysed the insurance market in Central, Eastern and Southeastern Europe and both countries which were analyzed in this research are contained in the sample. They used panel regression (a cross section with fixed effects) to examine the impact of GDP growth on insurance premium growth. The results suggest that economic development and catching-up processes mainly condition premium growth, and that in unstable periods, it shows increased volatility.

\section{COMPARATIVE ANALYSIS OF THE INSURANCE MARKET}

Figure 1 shows the total number of insurance companies operating in the insurance market in Serbia as well as in Bosnia and Herzegovina in the last ten years. The largest number of insurance companies in Serbia was present in the period 2011-2013 when there were 28 companies, followed by the decline in the number of insurance companies, ranging from 25 in 2014 to 21 at the end of 2017.

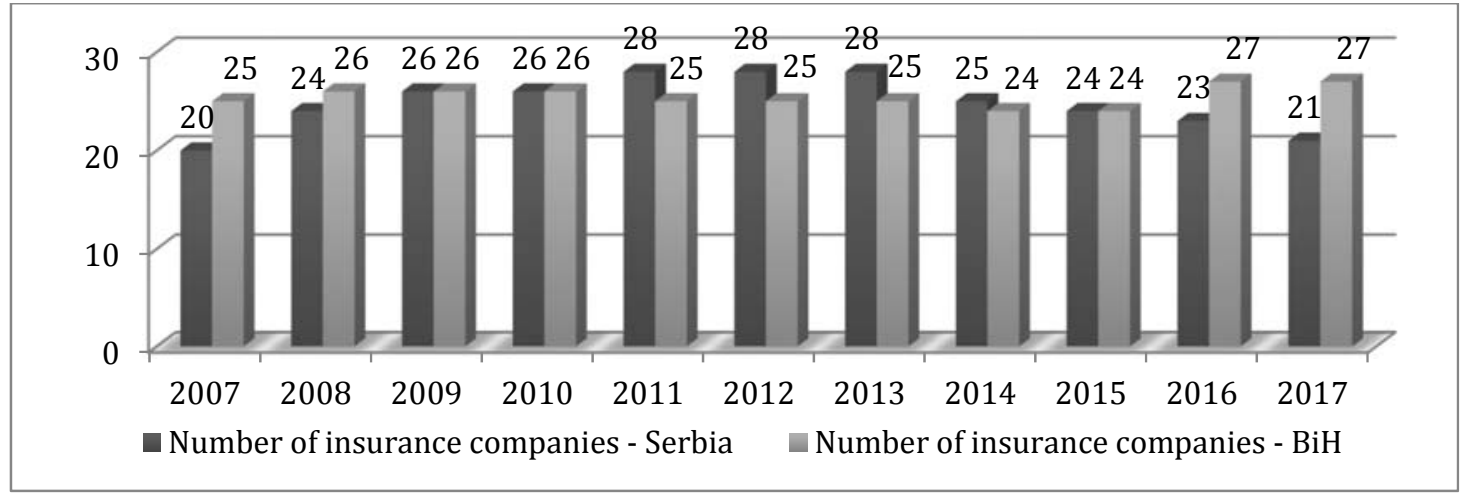

Figure 1. Number of insurance companies, 2007-2017

With the number of insurance companies in the market in Bosnia and Herzegovina, fewer oscillations can be noted in the observed period, ranging from 24 to 27 . The largest number of 
insurance companies at the $\mathrm{B} \& \mathrm{H}$ market operated in the last two years of the observed period, i.e. 2016-2017 with a total of 27 companies.

In addition to the banking sector with the largest share of the balance sheet total in the total financial sector - about $90 \%$, the balance sheets of the leasing companies, pension funds and insurance companies are included. Figure 2 shows a fall in the share of the insurance sector's balance sheet total in the total financial sector, which is notable in both markets in the period 2005-2008. After 2008, the share of the insurance sector balance sheet total in Serbia rose from $4.2 \%$ in 2008 to $6.3 \%$ in 2017. The same trend is present in the insurance market of Bosnia and Herzegovina, where the growth of the balance sheet total in the total financial sector increased in the same period for the same percentage $-2.1 \%$, from $3.45 \%$ to $5.57 \%$ in 2017 .

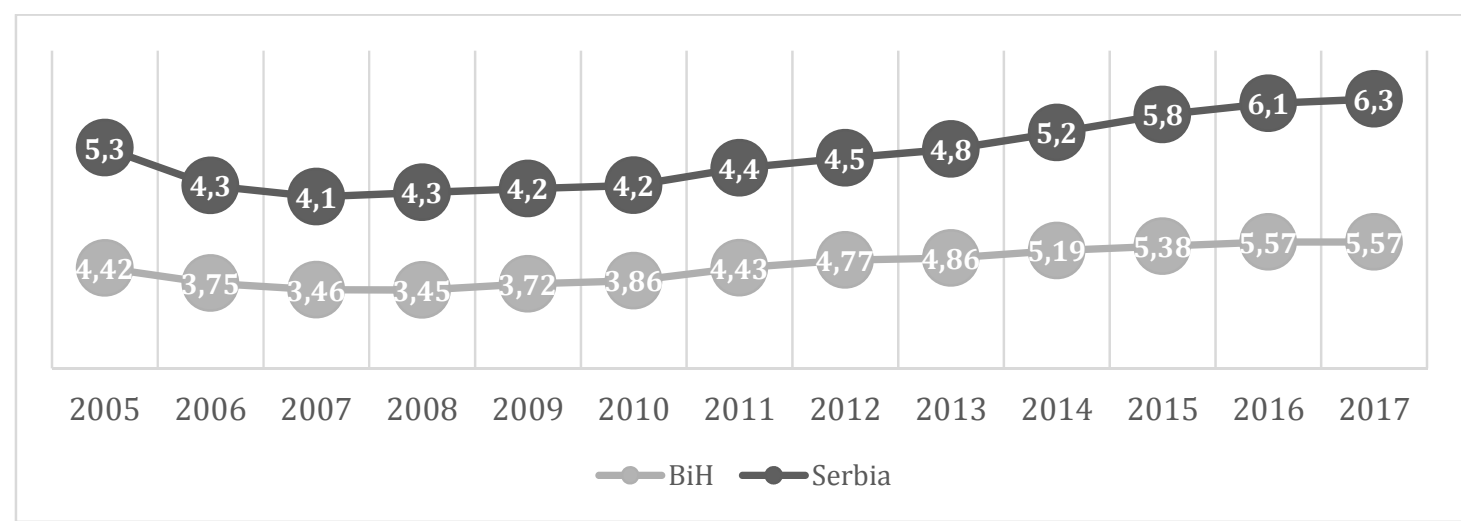

Figure 2. Contribution of the balance sheet total of the insurance sector to the overall financial sector, 2005-2017

Figures 3 and 4 show the ratio of the total number of insurance companies and foreign companies in the period 2007-2017. It can be concluded that the number of foreign insurance companies in Serbia has changed proportionally with the total number of companies present in the market. The number of foreign companies in the insurance market of B\&H did not change significantly in the observed period. There were 10 foreign insurance companies in the period 2008-2014, after which this number increased to 11 and 12 in 2015, 2016 and 2017, respectively.

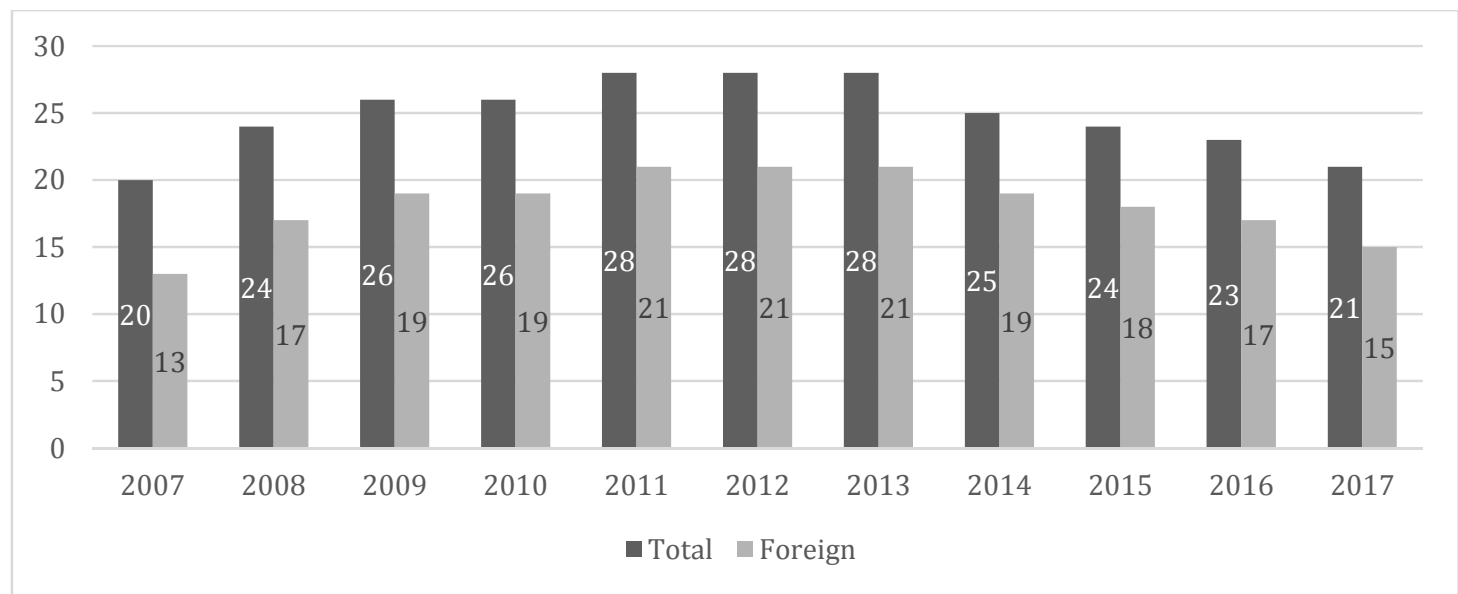

Figure 3. Relationship between the total number of insurance companies and foreign companies, 2007-2017, Serbia 


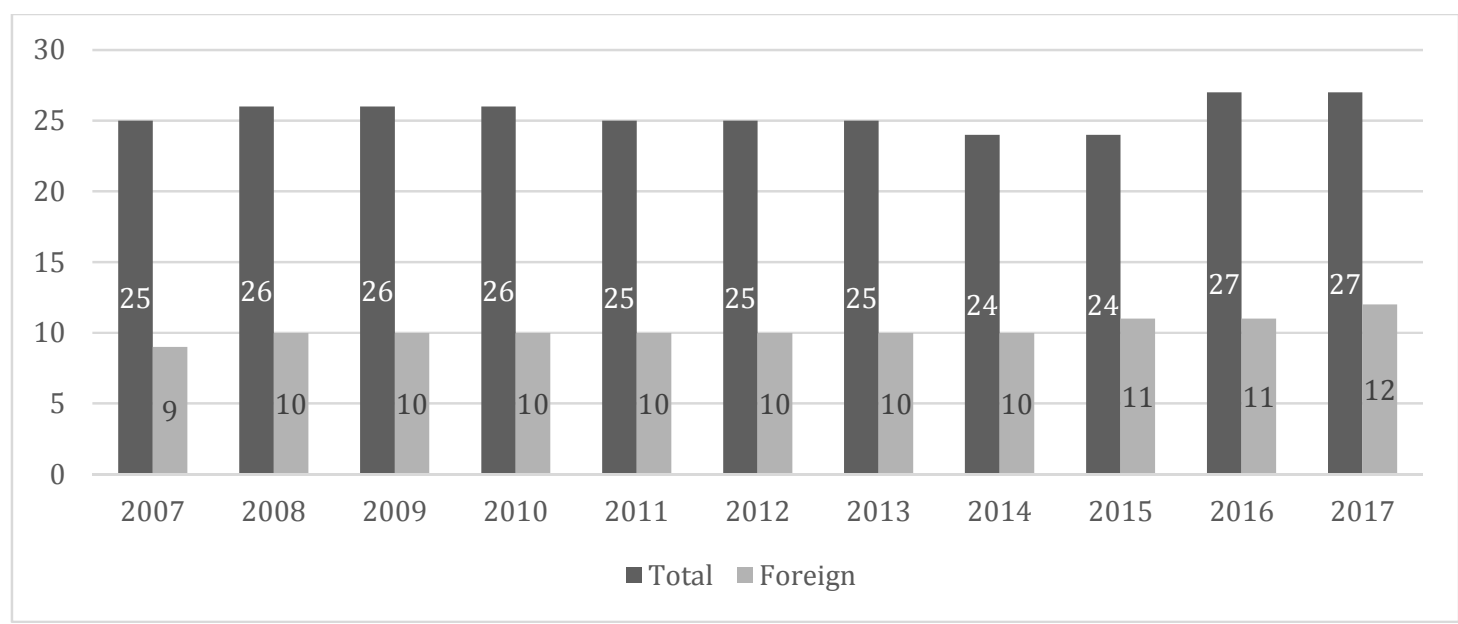

Figure 4. Relationship between the total number of insurance companies and foreign companies, 2007-2017, B\&H

Given that the subject matter of the analysis is the amount of income earned by insurance companies, the companies' market shares are calculated on the basis of the amount of total premiums at the end of the year taken from the balance sheet of insurance companies. Figure 5 shows a comparative analysis of the concentration of the largest companies in B\&H and Serbia according to the criterion of the total balance sheet. Dunav insurance company was the market leader in Serbia according to the mentioned criterion and has absorbed about one-quarter of the entire market in the observed period. By the end of 2015, Sarajevo Insurance was the market leader in $\mathrm{B} \& \mathrm{H}$ according to the criterion of the total premium. For the next two years of the observed period, Uniqa insurance achieved the largest amount of total premiums. The concentration of leader ratio in B\&H is much lower than in Serbia, so the leader in this market has a share of about one-tenth of the entire market.

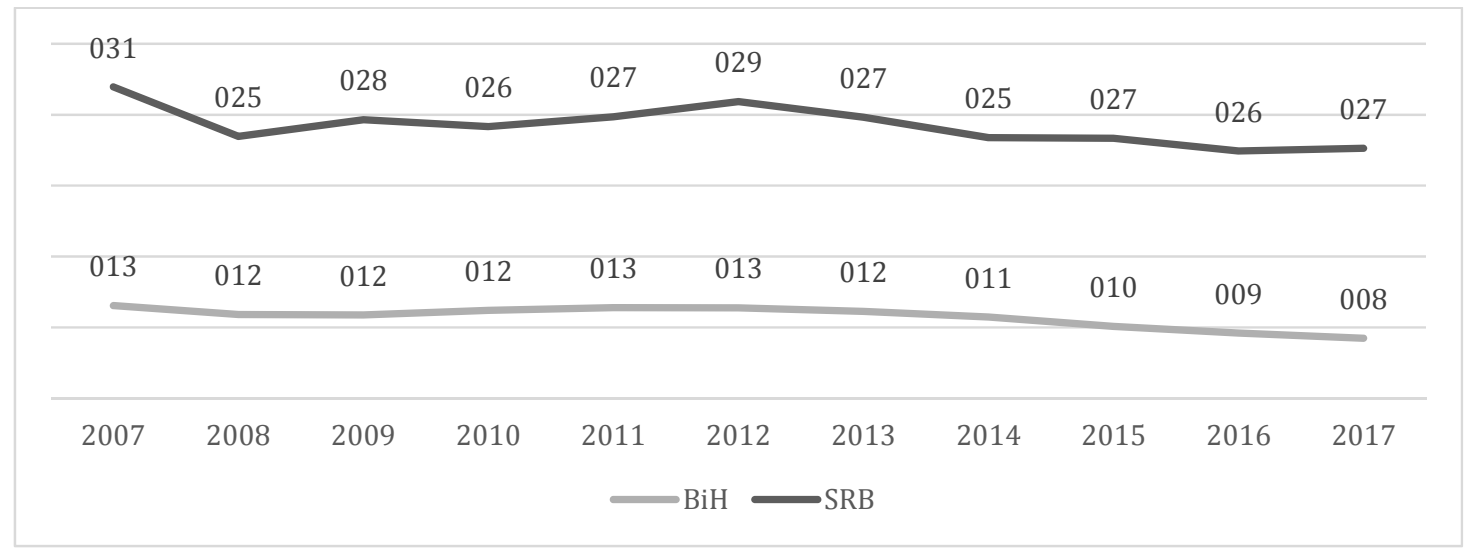

Figure 5. CR1 according to the criterion of the total premium, 2007-2017

The number of companies involved in the calculation of this indicator is determined by government agencies that are monitoring the degree of bid concentration in that particular country, provided that this coefficient is used as an official indicator (Martin, 2002). CR 1, CR3 and CR5 are most frequently accrued in the reports of the responsible insurance institutions, according to the criterion of total premiums, total non-life insurance premiums and total life 
assurance premiums. Figure 6 shows the concentration ratio of the top five insurance companies with the highest total premium. Although there is a mild tendency of market penetration at both markets, at the Serbian insurance market, the first five insurance companies have a much larger share than it is the case in Bosnia and Herzegovina. (as can be seen in Lorenz curves 8 and 9). CR5 had fallen from $84.16 \%$ in 2007 to $77.19 \%$ in 2017 . The mentioned concentration ratio in B\&H dropped from $45.97 \%$ to $39.21 \%$, from 2007 to 2017.

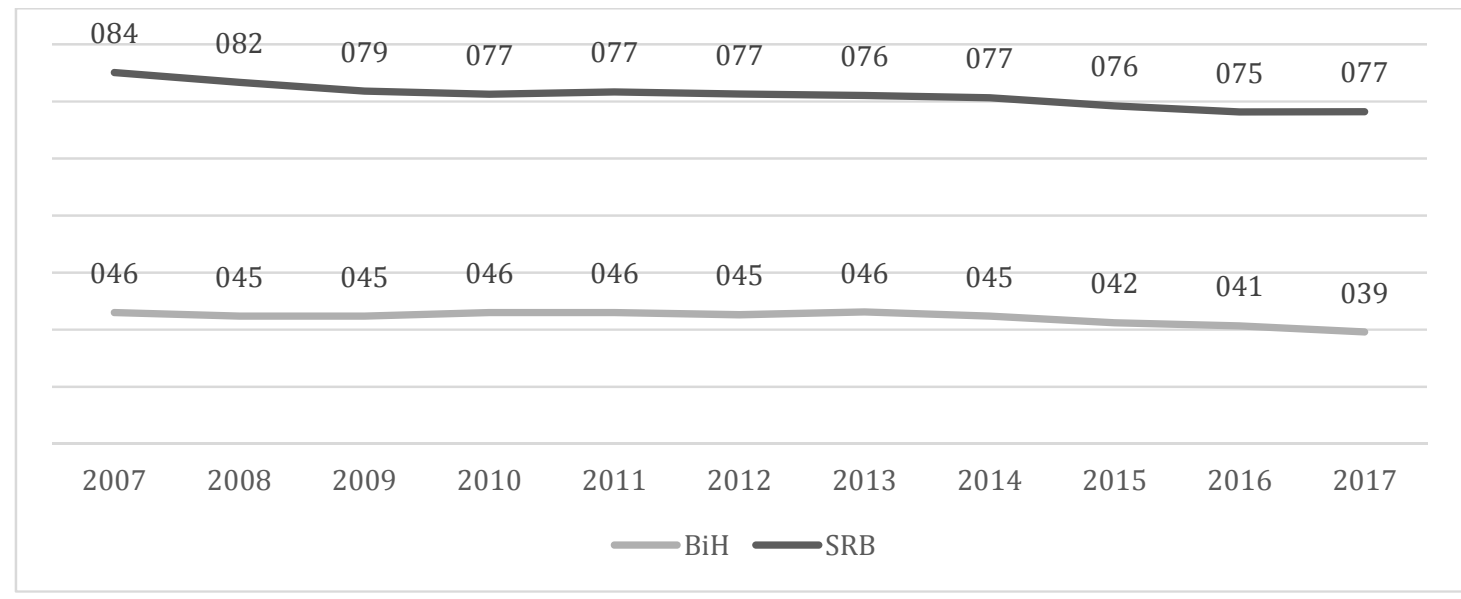

Figure 6. CR5 according to the criterion of the total premium, 2007-2017

Figure 7 shows the dynamic analysis of the Herfindahl-Hirschman index in the period 20072017 for both markets. The significance of the index is reflected in the fact that although it respects the individual market share of all companies in the branch it particularly responds to the presence of companies with large market participations, which significantly increase its value (Lipczynski \& Wilson, 2001) Given the above and taking into account the high CR5 concentration ratio on the insurance market of the Republic of Serbia, high values of the Herfindahl-Hirschman index are not surprising.

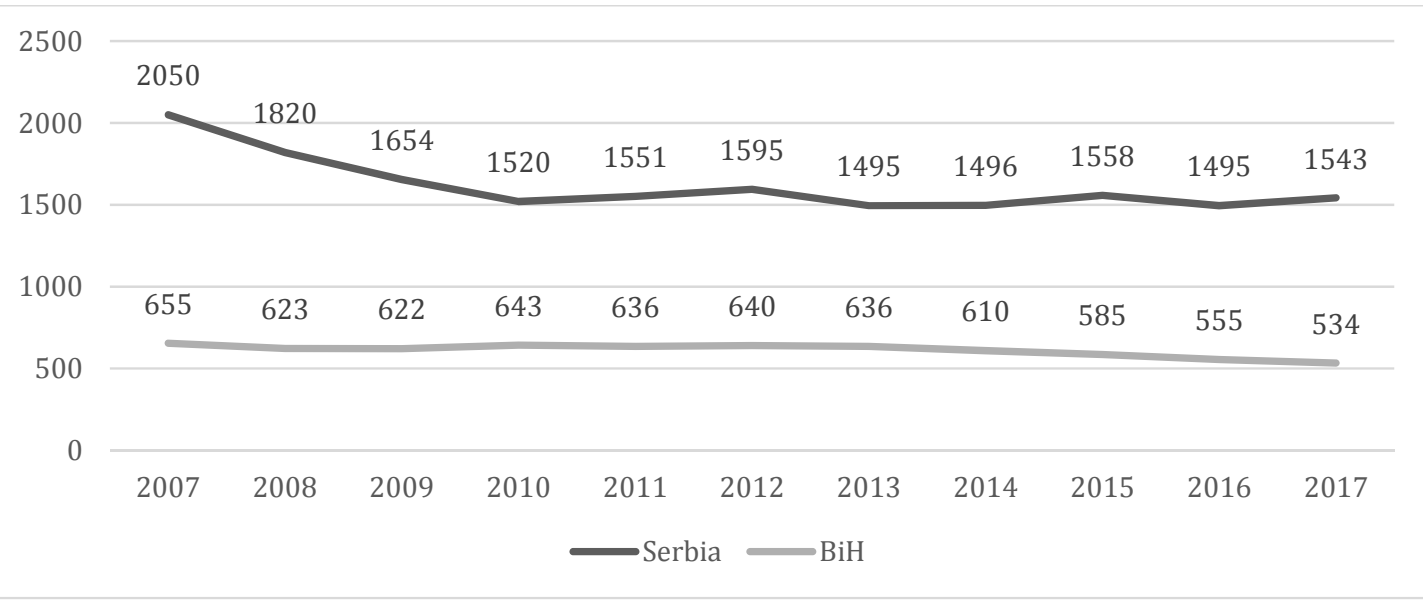

Figure 7. Herfindahl-Hirschman index according to the criterion of the total premium, 2007-017

With the increase in the number of insurance companies in Serbia, this index has declined, so the highly concentrated bid with the index of 2050 in 2007 reached the level of a medium concentrated bid (it is considered thin the market is medium concentrated if the HHI index value 
ranges from 1000 to 1800). It can be concluded that from 2008 until today, the insurance market in Serbia is medium concentrated. Herfindahl-Hirschman index according to the criterion of the total premium differs significantly in the market of Bosnia and Herzegovina, where the permanent low-concentration bid is present in the observed period. Although the HHI index fell from 655 to 534, from 2007 to 2017, it can be concluded that the insurance market in $\mathrm{B} \& \mathrm{H}$ is inconsistent, i.e. that there is greater equality of market share compared with the high inequality among market participants in the insurance sector of the Republic of Serbia.

Figure 8 shows Lorenz curves based on the amount of total premiums for the initial and the last year of the observed period, i.e. 2007 and 2017. First, insurance market leaders have reduced their market share, i.e. the top $20 \%$ of insurance companies in 2007 had a cumulative $80 \%$ of the total market share measured by the total premium, while the same percentage of leaders in 2017 had less than 60\%. With the exception of market leaders (the first four companies) of 18 companies in 2007, 14 companies shared $18.85 \%$ of the total market, while in the year 2017 some 15 companies shared 18.69\%, which suggests that the number of companies increased in the market with smaller market share, primarily due to the appearance of new companies in the market. This finding contributes to the value of the Herfindahl-Hirschman index as well as the value of CR5.
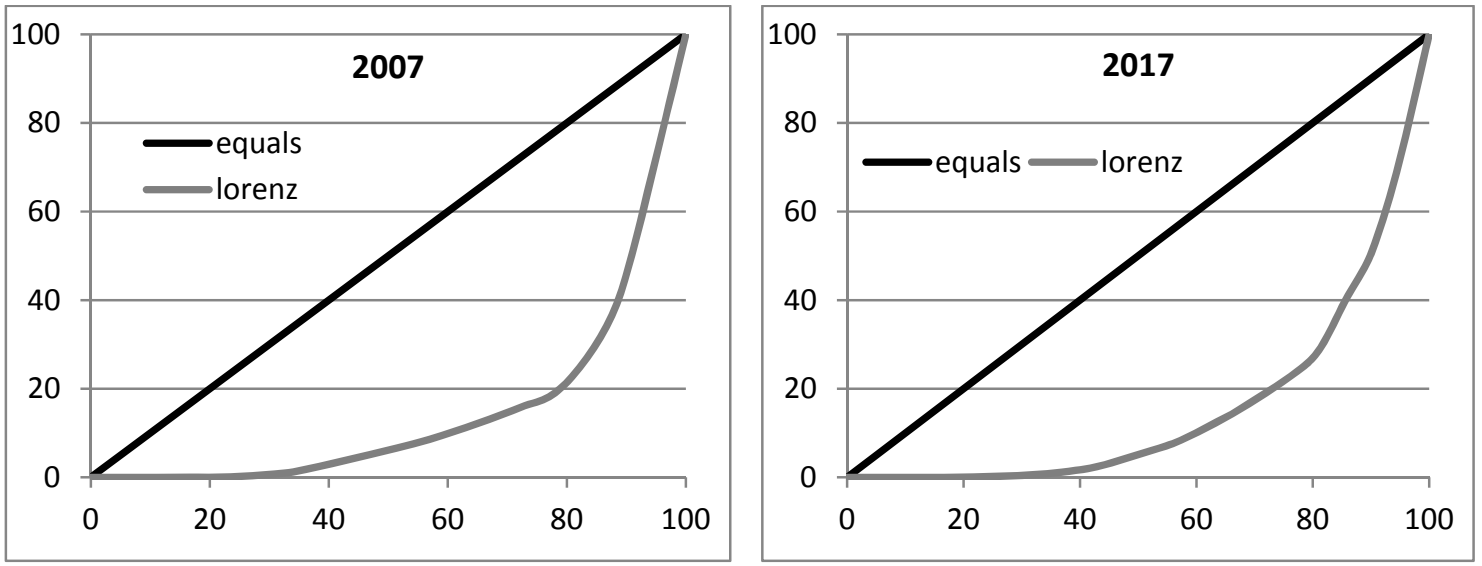

Figure 8. Lorenz curve and Herfindahl-Hirschman index according to the criterion of the total premium, 2007-2017, Serbia

Constructing Lorenz's curve in terms of the degree of concentration of supply in the relevant market, the distribution of the entire market between business entities can be clearly seen. (Kaličanin \& Hanić 2016b). Lorenz curves for the insurance market of Bosnia and Herzegovina constructed based on the premiums shown in Figure 9 differ considerably from those presented in Figure 8. The distribution of the market share of insurance companies in the stipulated market is characterised by greater equality, which can be inferred from the Lorenz curve distance from the equal's curves (in case of equal distribution of market share among all participants in the market). Fewer companies have been able to increase their market share over the observed period, while market leaders reduced their cumulative market share. 

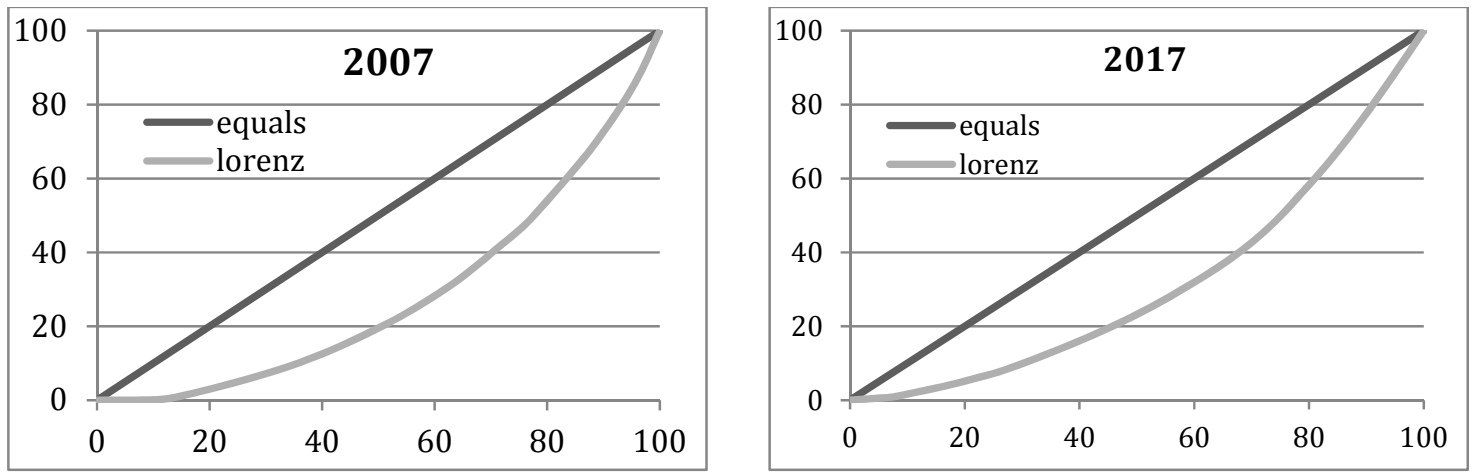

Figure 9. Lorenz curve and Herfindahl-Hirschman index according to the criterion of the total premium, 2007-2017, B\&H

In 2017 in Bosnia and Herzegovina, there were 27 companies, i.e. 6 companies more than in the Republic of Serbia. In addition to the difference in the number of companies, there is greater inequality in the distribution of market shares in the Serbian insurance market as well as greater concentration on the supply side compared to the low concentration of the insurance market of Bosnia and Herzegovina.

\section{METHODOLOGY}

As emphasised before, the aim of this paper is to analyse the insurance market in Serbia and Bosnia and Herzegovina with reference to certain macroeconomic indicators that play a key role in the development of insurance. In this respect, we investigated the mutual influence of individual variables on the movement of total premium income earned in these countries. In this analysis, a time series is used for the period 2000-2017, i.e. for a period of 18 years. For the mentioned period, the following independent variables were analysed:

- $X_{1}$ - Average net salary (current, RSD/KM)

- $X_{2}$ - Unemployment, total (\% of the otal labor force)

- $X_{3}$ - Gross domestic income (constant LCU)

- $X_{4}$ - GDP per capita (current US\$)

- $X_{5}$ - Wage and salaried workers, total (\% of total employment)

- $X_{6}$ - Households and NPISHs Final consumption expenditure (current US\$)

while the dependent variable $Y$ was - Total premium (current RSD/KM).

For this research, multiple regression analysis was carried out using the SPSS statistical software.

The choice of independent variables is based on empirical fundaments that relate to the studied variable, as well as on the information contained in the relevant literature. Six independent variables were included in the analysis to identify those that could explain the major part of the variability of the studied (dependent) variables. A model involving variables whose calculated regression coefficient is significant at $5 \%$ level is selected.

\section{EMPIRICAL RESEARCH AND DISCUSSION}

Usually, the first part of the study contains basic indicators of descriptive statistics. Since all variables included in the analysis were measured on the ratio scale, the values of arithmetic mean and standard deviations are presented as indicators of a descriptive statistic (Table 1 and Table 2). 
Table 1: Descriptive statistics for different variables - Serbia

\begin{tabular}{|l|r|r|r|}
\hline & \multicolumn{1}{|c|}{ Mean } & \multicolumn{1}{c|}{ Std. Deviation } & N \\
\hline Total premium & 49372718.5000 & 24831359.35237 & 18 \\
\hline Average net salary & 345729.3333 & 183811.84680 & 18 \\
\hline $\begin{array}{l}\text { Unemployment, total (\% of total labor } \\
\text { force) }\end{array}$ & 17.6239 & 3.61340 & 18 \\
\hline Gross domestic income (constant LCU) & 2855342777777.7780 & 458570337497.97485 & 18 \\
\hline GDP per capita (current US\$) & 4614.9873 & 1798.25314 & 18 \\
\hline $\begin{array}{l}\text { Wage and salaried workers, total (\% of } \\
\text { total employment) }\end{array}$ & 69.4582 & 1.98410 & 18 \\
\hline $\begin{array}{l}\text { Households and NPISHs Final } \\
\text { consumption expenditure (current US\$) }\end{array}$ & 25301236558.1667 & 9670960437.31504 & 18 \\
\hline
\end{tabular}

Source: Authors using SPSS

Table 2: Descriptive statistics for different variables - BiH

\begin{tabular}{|l|r|r|r|}
\hline & \multicolumn{1}{|c|}{ Mean } & \multicolumn{1}{|c|}{ Std. Deviation } & N \\
\hline Total premium & 430206288.0000 & 141434498.99548 & 18 \\
\hline Average net salary & 1035.7778 & 262.30260 & 18 \\
\hline $\begin{array}{l}\text { Unemployment, total (\% of total labor } \\
\text { force) }\end{array}$ & 27.3079 & 2.00943 & 18 \\
\hline Gross domestic income (constant LCU) & 24073220032.1667 & 3036558289.97812 & 18 \\
\hline GDP per capita (current US\$) & 3848.6667 & 1366.86275 & 18 \\
\hline $\begin{array}{l}\text { Wage and salaried workers, total (\% of } \\
\text { total employment) }\end{array}$ & 66.5221 & 6.48730 & 18 \\
\hline $\begin{array}{l}\text { Households and NPISHs Final } \\
\text { consumption expenditure (current US\$) }\end{array}$ & 12811176132.8333 & 2684992943.38614 & 18 \\
\hline
\end{tabular}

Source: Authors using SPSS

Below is an output that refers to the multiple regression model which was implemented on the data obtained for both countries involved in the analysis.

Table 3: Model summary along with the values of R and R square - Serbia

\begin{tabular}{|c|c|c|c|c|c|c|c|c|c|}
\hline \multirow[b]{2}{*}{ Model } & \multirow[b]{2}{*}{$\mathbf{R}$} & \multirow{2}{*}{$\begin{array}{c}\text { R } \\
\text { Square }\end{array}$} & \multirow{2}{*}{\begin{tabular}{|c|} 
Adjusted \\
R \\
Square
\end{tabular}} & \multirow{2}{*}{$\begin{array}{l}\text { Std. Error of } \\
\text { the Estimate }\end{array}$} & \multicolumn{5}{|c|}{ Change Statistics } \\
\hline & & & & & $\begin{array}{c}\text { R Square } \\
\text { Change }\end{array}$ & $\begin{array}{c}\text { F } \\
\text { Change }\end{array}$ & df1 & df2 & $\begin{array}{c}\text { Sig. F } \\
\text { Change }\end{array}$ \\
\hline 1 & $.962^{\mathrm{a}}$ & .925 & .920 & 7023512.91992 & .925 & 196.491 & 1 & 16 & .000 \\
\hline 2 & $.981^{b}$ & .962 & .957 & 5152189.94256 & .037 & 14.733 & 1 & 15 & .002 \\
\hline 3 & $.992^{c}$ & .983 & .980 & 3548389.97989 & .021 & 17.624 & 1 & 14 & .001 \\
\hline 4 & $.996^{\mathrm{d}}$ & .993 & .990 & 2444365.32992 & .009 & 16.502 & 1 & 13 & .001 \\
\hline
\end{tabular}

a. Predictors: (Constant), Average net salary

b. Predictors: (Constant), Average net salary, Households and NPISHs Final consumption expenditure (current US\$)

c. Predictors: (Constant), Average net salary, Households and NPISHs Final consumption expenditure (current US\$), Gross domestic income (constant LCU)

d. Predictors: (Constant), Average net salary, Households and NPISHs Final consumption expenditure (current US\$), Gross domestic income (constant LCU), Unemployment, total (\% of total labor force)

Source: Authors using SPSS 
In the case of variables describing the insurance market in the Republic of Serbia, four models were generated, where the last model was selected having the highest value of the coefficient $R^{2}$. The $R^{2}$ value in this case shows that $99.3 \%$ variations in total premium can be explained by selected four variables and this model can be considered appropriate to develop the regression equation. The independent variables selected by the above mentioned model are as follows: Average net salary, Households and NPISHs Final consumption expenditure, Gross domestic income and Unemployment, total (Table 3).

The following table shows the unstandardized and standardised regression coefficients for all models. In the last model, t-values for all the two regression coefficients are significant as their significance values ( $p$-values) are less than 0.05. Therefore, it can be concluded that the previously selected 4 independent variables significantly explain the variations in the total premium.

Table 4: Regression coefficients of selected variables in different models along with their $t$ values and partial ccorrelations - Serbia

\begin{tabular}{|c|c|c|c|c|c|c|c|c|c|}
\hline & \multirow{2}{*}{ Model } & \multicolumn{2}{|c|}{ Unstandardized Coefficients } & \multirow{2}{*}{\begin{tabular}{|c|}
$\begin{array}{c}\text { Standardised } \\
\text { Coefficients }\end{array}$ \\
Beta \\
\end{tabular}} & \multirow[b]{2}{*}{$\mathbf{t}$} & \multirow{2}{*}{ Sig. } & \multicolumn{3}{|c|}{ Correlations } \\
\hline & & B & Std. Error & & & & $\begin{array}{l}\text { Zero- } \\
\text { order }\end{array}$ & Partial & Part \\
\hline \multirow[t]{2}{*}{1} & (Constant) & 4460520.406 & 3606405.932 & & 1.237 & .234 & & & \\
\hline & Average net salary & 129.906 & 9.267 & .962 & 14.018 & .000 & .962 & .962 & .962 \\
\hline \multirow[t]{3}{*}{2} & (Constant) & 14150355.208 & 3656718.281 & & 3.870 & .002 & & & \\
\hline & Average net salary & 178.058 & 14.268 & 1.318 & 12.479 & .000 & .962 & .955 & .628 \\
\hline & $\begin{array}{l}\text { Households and } \\
\text { NPISHs Final } \\
\text { consumption } \\
\text { expenditure }\end{array}$ & -.001 & .000 & -.405 & -3.838 & .002 & .753 & -.704 & -.193 \\
\hline \multirow[t]{4}{*}{3} & (Constant) & -66019515.273 & 19262250.240 & & -3.427 & .004 & & & \\
\hline & Average net salary & 102.779 & 20.448 & .761 & 5.026 & .000 & .962 & .802 & .174 \\
\hline & $\begin{array}{l}\text { Households and } \\
\text { NPISHs Final } \\
\text { consumption } \\
\text { expenditure }\end{array}$ & -.002 & .000 & -.640 & -6.977 & .000 & .753 & -.881 & -.242 \\
\hline & $\begin{array}{l}\text { Gross domestic } \\
\text { income }\end{array}$ & $4.254 \mathrm{E}-5$ & .000 & .786 & 4.198 & .001 & .934 & .747 & .145 \\
\hline \multirow[t]{5}{*}{4} & (Constant) & -49098413.472 & 13907538.352 & & -3.530 & .004 & & & \\
\hline & Average net salary & 107.565 & 14.135 & .796 & 7.610 & .000 & .962 & .904 & .182 \\
\hline & $\begin{array}{l}\text { Households and } \\
\text { NPISHs Final } \\
\text { consumption } \\
\text { expenditure }\end{array}$ & -.001 & .000 & -.550 & -8.200 & .000 & .753 & -.915 & -.196 \\
\hline & $\begin{array}{l}\text { Gross domestic } \\
\text { income }\end{array}$ & $3.880 \mathrm{E}-5$ & .000 & .717 & 5.512 & .000 & .934 & .837 & .132 \\
\hline & $\begin{array}{l}\text { Unemployment, } \\
\text { total (\% of total } \\
\text { labor force) }\end{array}$ & -783350.327 & 192833.041 & -.114 & -4.062 & .001 & .250 & -.748 & -.097 \\
\hline
\end{tabular}

a. Dependent Variable: Total premium

Source: Authors using SPSS

Using the values of the unstandardized regression coefficients of the last model presented in Table 4, the following regression model can be shown:

Total premium

$$
\begin{aligned}
& =-49098413.472+107.565 \text { Average net salary } \\
& -0.001 \text { Households and NPISHs Final consumption expenditure } \\
& +0.0000388 \text { Gross domestic income }-783350.327 \text { Unemployment total }
\end{aligned}
$$


Concerning the same analysis carried out for the data from Bosnia and Herzegovina, two models were generated, where the second one was selected for which the value of 0.983 was assigned for the determination coefficient (Table 5). In this way, a multiple hierarchy model was formulated which combines two independent variables as follows: Gross domestic income and Wage and salaried workers, total. Since the F-value for this model is highly significant, the model is reliable. Also, the regression coefficients in the stipulated model are statistically significant, and it is considered that the selected variables have a great predictive significance in estimating the value of the Total premium.

Table 5: Model summary along with the values of R and R square - BIH

\begin{tabular}{|c|c|c|c|c|c|c|c|c|c|}
\hline \multirow[b]{2}{*}{ Model } & \multirow[b]{2}{*}{$\mathbf{R}$} & \multirow[b]{2}{*}{$\begin{array}{c}\text { R } \\
\text { Square }\end{array}$} & \multirow[b]{2}{*}{$\begin{array}{l}\text { Adjusted R } \\
\text { Square }\end{array}$} & \multirow[b]{2}{*}{$\begin{array}{l}\text { Std. Error of the } \\
\text { Estimate }\end{array}$} & \multicolumn{5}{|c|}{ Change Statistics } \\
\hline & & & & & $\begin{array}{l}\text { R Square } \\
\text { Change }\end{array}$ & \begin{tabular}{|c|}
$\mathbf{F}$ \\
Change
\end{tabular} & df1 d & df2 & $\begin{array}{c}\text { Sig. F } \\
\text { Change }\end{array}$ \\
\hline 1 & $.975^{\mathrm{a}}$ & .951 & .948 & 32128444.21790 & .951 & 313.443 & 1 & 16 & .000 \\
\hline 2 & $.992^{b}$ & .983 & .981 & 19491967.96979 & .032 & 28.470 & 1 & 15 & .000 \\
\hline
\end{tabular}

a. Predictors: (Constant), Gross domestic income (constant LCU)

b. Predictors: (Constant), Gross domestic income (constant LCU), Wage and salaried workers, total (\% of total employment)

Source: Authors using SPSS

The last table contains the values of the regression coefficients for the previously selected model.

Table 6: Regression coefficients of selected variables in different models along with their $t$ values and partial correlations - BIH

\begin{tabular}{|c|c|c|c|c|c|c|c|c|c|}
\hline \multirow{2}{*}{\multicolumn{2}{|c|}{ Model }} & \multicolumn{2}{|c|}{$\begin{array}{l}\text { Unstandardized } \\
\text { Coefficients }\end{array}$} & \multirow{2}{*}{\begin{tabular}{|c|}
$\begin{array}{c}\text { Standardised } \\
\text { Coefficients }\end{array}$ \\
Beta \\
\end{tabular}} & \multirow{2}{*}{$\mathbf{t}$} & \multirow{2}{*}{ Sig. } & \multicolumn{3}{|c|}{ Correlations } \\
\hline & & B & Std. Error & & & & $\begin{array}{l}\text { Zero- } \\
\text { order }\end{array}$ & Partial & Part \\
\hline 1 & (Constant) & -663490820.738 & 62238137.572 & & -10.661 & .000 & & & \\
\hline & $\begin{array}{l}\text { Gross domestic } \\
\text { income }\end{array}$ & .045 & .003 & .975 & 17.704 & .000 & .975 & .975 & .975 \\
\hline 2 & (Constant) & -827546449.311 & 48694106.929 & & -16.995 & .000 & & & \\
\hline & $\begin{array}{l}\text { Gross domestic } \\
\text { income }\end{array}$ & .035 & .002 & .759 & 14.452 & .000 & .975 & .966 & .483 \\
\hline & $\begin{array}{l}\text { Wage and } \\
\text { salaried } \\
\text { workers, total } \\
\text { (\% of total } \\
\text { employment) }\end{array}$ & 6110923.803 & 1145287.155 & .280 & 5.336 & .000 & .866 & .809 & .178 \\
\hline
\end{tabular}

a. Dependent Variable: Total premium

Source: Authors using SPSS

Regression equation, which can explain the variability of the observed Total premium variable analysing trends in selected independent variables goes as follows:

Total premium

$=-827546449.311+0.035$ Gross domestic income
+6110923.803 Wage and salaried workers 


\section{CONCLUSION}

After 2008, the share of the insurance sector balance sheet total in Serbia and Bosnia and Herzegovina increased in the same period for the same percentage $-2.1 \%$. The number of insurance companies with foreign equity in Serbia has changed proportionally with the total number of companies present in the market whereas the number of the foreign insurance companies in Bosnia and Herzegovina remained almost the same although the total number of the insurance companies increased. The concentration of leader ratio (CR1) in Bosnia and Herzegovina is much lower than in Serbia, so the leader in this market has a share of about $10 \%$ of the entire market while in Serbia it is about $27 \%$. Although there is a moderate tendency of market penetration at both markets, at the Serbian insurance market, the first five insurance companies have a much larger share than it is the case in Bosnia and Herzegovina. It can be concluded that in the last decade the insurance market in Serbia is medium concentrated according to Herfindahl-Hirschman index calculated by total premium and it differs significantly in the market of Bosnia and Herzegovina, where permanent low-concentration bid is present in the observed period - there is greater equality of market share compared with the high inequality among market participants in the insurance sector of the Republic of Serbia.

In this paper, the multi-linear regression model was applied in order to analyse the impact of selected macroeconomic indicators on the amount of insurance premiums in the period 20002017. We can conclude that the greatest impact on the amount of the premium in Bosnia and Herzegovina had Gross Domestic Income and Wage and Salaries Workers. In the Republic of Serbia, the greatest influence on the amount of premium in the observed period had Average Net Salary, Households and Final Consumption Expenditure and Gross Domestic Income. Therefore, there is a positive correlation between household income (including salary and other income) and premiums. Also, in the periods when household expenditure was higher, the amount of total insurance premium was also higher.

Both of the selected economies have undergone changes in the financial sector, particularly in terms of recent regulatory reforms. This paper provides information on the determinants of insurance demand in the Republic of Serbia and Bosnia and Herzegovina. This research is limited to a macro level analysis of the insurance demand. Further, detailed analysis can be performed on individual life insurance products, which may result in more reliable findings. The period 2000-2017 was analysed, so future studies can further segregate the CEE region into developed and developing economies and make a detailed time series analysis incorporating both pre-crisis and post-crisis period.

\section{ACKNOWLEDGEMENTS}

This paper is a result of research projects under the code 179015 (Challenges and Prospects of Structural Changes in Serbia: Strategic Directions for Economic Development and harmonisation with EU requirements) financed by the Ministry of Science and Technological Development of the Republic of Serbia.

\section{REFERENCES}

Beck, T. \& Webb, I. (2003). "Economic, demographic and institutional determinants of life insurance consumption", The World Bank Economic Review, 17(1): 51-88., doi: 10.1093/wber/lhg011.

Bianchi, T., Ebner, G., Korherr, R. \& Ubl, E. (2011). "The Austrian Insurance Industry in CESEE: Risks and Opportunities from a Financial Stability Point of View." Financial Stability Report 22 [Internet], pp. 88-106. Available at: https://www.researchgate.net/profile/Eva_Ubl/publication/227462654_The_Austrian_Insur 
ance_Industry_in_CESEE_Risks_and_Opportunities_from_a_Financial_Stability_Point_of_View/l inks/0deec53b4fe428fd37000000.pdf (Accessed: 28 March 2019).

Burić Novović, M., Cerović Smolović, J., Lipovina Božović, M. \& Lalević Filipović, A. (2017). "Impact of economic factors on life insurance development in Western Balkan Countries." Zbornik radova Ekonomskog fakulteta $u$ Rijeci 35, br. 2: 331-352. https://doi.org/10.18045/zbefri.2017.2.331.

Dragos, S. (2014). "Life and non-life insurance demand: the different effects of influence factors in emerging countries from Europe and Asia". Economic Research Ekonomska Istraživanja, 27(1): 169-180, doi: 10.1080/1331677x.2014.952112.

Haiss, P. \& Sümegi, K. (2008). "The relationship between insurance and economic growth in Europe: a theoretical and empirical analysis" Empirica, 35(4): 405-431, doi: 10.1007/s10663008-9075-2.

Kaličanin, T. \& Hanić, A. (2016a). "Comparative Analysis of Levels of Banking Sector Markets Concentration in CEE Region." Economic Analysis, 49(1-2) 59-72.

Kaličanin, T. \& Hanić, A. (2016b). "Analiza koncentracije u finansijskom sektoru." In: Pravci strukturnih promena u procesu pristupanja Evropskoj uniji, ed. Minović, Jelena, Duško Bodroža, Ivan Stošić, and Božo Drašković, 308-324. Belgrade: Institute of economic sciences.

Kaličanin, T. \& Lazić, M. (2018). "Evaluating the Level of Market Concentration in Insurance Sector: the case of Serbia." In: Western Balkans Economies in EU Integration, past, present and future, ed. Richet, Xavier, Dejan Erić, Srđan Redžepagić, Ivan Stošić and Duško Bodroža, 202221. Nice: CEMAFI International Association.

Kjosevski, J. (2012). "The determinants of life insurance demand in central and Southeastern Europe". International Journal of Economics and Finance, 4(3): pp. 237-247, doi: $10.5539 /$ ijef.v4n3p237.

Lipczynski, J. \& John, W. (2001). Industrial Organization: An Analysis of Competitive Markets. Prentice-Hall, London.

Martin, S. (2002). Advanced Industrial Economics. Blackwell Publishers Ltd, Oxford.

Mitra, A. (2017). "Influencers of Life Insurance Investments: Empirical Evidence from Europe". Australasian Accounting, Business and Finance Journal, 11(3): 87-102. https://doi.org/10.14453/aabfj.v11i3.7.

Outreville, F. (1990). "The Economic Significance of Insurance Markets in Developing Countries." The Journal of Risk and Insurance 57, no. 3: 487-98. doi:10.2307/252844.

Ward, D. \& Zurbruegg, R. (2002). "Law, Politics and Life Insurance Consumption in Asia", Geneva Papers on Risk and Insurance, 27(3): 395-412. doi:10.1111/1468-0440.00181.

Webb, I., Martin, G. \& Skipper, H. (2002). "The Effect of Banking and Insurance on the Growth of Capital and Output". Centre for Risk Management and Insurance, Working Paper, No. 02-1. Robinson College of Business, Georgia State University, Atlanta.

Zhi, Z. (1998). Die Nachfrage nach Lebensversicherungen: Eine empirische Analyse für China, Mannheimer Manuskripte zu Risikotheorie, Portfolio Management und Versicherungswirtschaft 112, Universität Mannheim.

www.nbs.rs

www.azobih.gov.ba

www.data.worldbank.org

Article history: $\quad$ Received: April 1, 2019

Accepted: May 29, 2019 